\title{
ISLAMIC PRAYER, SPIRITUALITY, AND PRODUCTIVITY: AN EXPLORATORY CONCEPTUAL ANALYSIS
}

\author{
M Ashraf Al Haq, Norazlina Abd Wahab, \\ Hj. Abdullah Abd Ghani, Nor Hayati Ahmad
}

\begin{abstract}
Islamic Prayer, Spirituality and Productivity: An Exploratory Conceptual Analysis. Prayer plays a noteworthy role in Muslims daily lives. Quran and Sunnah testify that regular prayers can boost one's health, can remove the level of stress, and may make one more productive and vigour. Such findings also noticed by medical and psychological experts, and likewise many contemporary research have shown wide-ranging outcomes in terms of improved wellbeing when prayer is done with sincere devotion. Nevertheless what is lacking is that the policy makers in the Islamic world need to initiate whether there exist any linkages between prayer and productivity, which needs to be appreciated more by them, as well as by Islamic economists and social scientists, Islamic business professionals and Islamic jurists, and then through a concerted effort and dynamic fact finding mission and verification to ascertain the Qur'anic beliefs in our daily lives. This studies using descriptive analysis to explain the linkage between the Islamic prayer and productivity.
\end{abstract}

Keywords: religion; spirituality; Islamic prayer; productivity

Abstrak: Ibadah, Spiritualitas, dan Produktivitas: Analisis Konseptual Eksplorasi. Ibadah mengambil peranan penting dalam aktivitas keseharian seorang muslim. Qur'an dan Sunnah menyebutkan bahwa ibadah yang rutin dilakukan dapat meningkatkan kesehatan seseorang, mengurangi tingkat stres, dan meningkatkan produktivitas dan semangat. Beberapa temuan turut pula menekankan berdasarkan pandangan dari sisi kesehatan dan ahli, , serta beberapa penelitian telah pula menjelaskan keluaran akan sikap dan perilaku yang lebih baik ketika ibadah dilaksanakan untuk mengurangi dosa. Namun masih sedikit bahasan terkait keterkaitan antara ibadah yang dilaksanakan dengan tingkat produktivitas, dimana hal ini harus diapresiasi oleh para ekonom dan ilmuan muslim, pelaku bisnis Islam, dan para abli hukum Islam. Kemudian melalui upaya bersama dan misi pencarian fakta yang dinamis dan verifikasi untuk memastikan keyakinan Qur'an dalam kehidupan keseharian kita. Kajian ini menggunakan analisis deskriptif untuk menjelaskan keterkaitan antara ibadah dengan produktivitas.

Kata kunci: agama; spiritualitas; ibadah Islam; produktivitas 


\section{Introduction}

As opposed to prayers in some isms, religious dogmas or beliefs, Islamic prayer is essentially a spiritual phenomenon and entire understanding towards this end, evolves around the equivalent concept interchangeably. In contemporary studies it is found that, spirituality, religious practices and prayers, improve ethical behaviour (Jewe, 2008), and this improvement helps in productivity increment (Sims, 1994). Besides, when people pray with sincerity and vigour, it helps them to seek eternal heavenly blessings and that in turn, helps that individual to gain enormous energy, which only that seeker can explain and at times it cannot be enumerated. Stainer et al. (1995) noted, "It is the combination of productivity, quality and ethics which will establish the management culture of the future". Such linkages are necessary to be established in Islamic paradigm. A research in Islamic paradigm is due, to observe such linkages, so it may boost empirical evidences. Spirituality is the most discussed topic in recent years (Spohn, 2001) Here moreover, it is noted that the economics of religion can be traced from Adam Smith's writings, who wrote The Theory of Moral Sentiments, and again from 1970s the subject of ethics, religion, spirituality and morality started gaining momentum (Mangeloja, 2003).

The reason of gaining momentum stemmed from the belief that an ethical employee can bring greater result and increased productivity in businesses, economy and so on, as the mere ethics-free value system failed to address the falling of economic integers in the west (Burke et al. 1990). Burke et al. (1990) explained the reason behind the productivity collapse that was due to lack of ethics, lack of spiritual dimension and exclusion of value in the western value-free system. At the same time the Mecca declaration of the 1977 (Saqeb 2000), has prompted the Muslim world to bring forward the Islamic values in the educational and social forefront. Islamic prayers, whether rituals i.e., Haqqullah, like prayers and Hajj for spiritual refinement, or Haqqul-ibad, like zakat or sadaqat, which may bring not only cleanliness in the seeker's heart (Quranic Ayat 9.103, 98.5), but will also help to increase productivity or Baraka (Surah An Nisa, verse 29).

The paper has seven parts. After the initial introduction and the objectives underlined, the second section includes the motivation of study, in the third section, the findings in the contemporary literature briefly reviewed, fourthly the Islamic manifestations is highlighted, and in the fifth section the connectivity with salat is emphasised and in the sixth section such as: in conclusion, a recommendation has been made. The references are in the last section. The paper is written from library research, and as a tentative initiative, requires further research to be instigated to see the empirical outcomes of the Qur'anic explanations from social perspectives in our daily lives. 
The aim of this piece of initiative is to ignite a spark in the Islamic arena to discover whether there rests any linkages between Islamic prayers and productivity and that can truly lead to an increase in economic output. In the contemporary studies, it has been observed that there is a correlation that exists between prayer, spirituality and productivity. Enormous writings have taken place as well, even in an Islamic framework, and stacks of research available on the internet by casual researchers and lovers of Islam, but academic researchers need to objectively treasure whether any further deductions can be established through empirical outcomes. Although there are many studies covering the relationship between prayer and spirituality in Islam discussed, but the gap identified in the present literature is that there is a lack of effort to link the three elements: prayer, spirituality and productivity together in an Islamic framework, and from a social scientists point of view. Although financial prayer has been linked to productivity and discussed, but the overall prayers' combined link to productivity aspect, is what the present paper feels is still lacking. In this paper, several relevant Quranic verses, Hadiths and also findings (from medical and conventional wisdom) are presented and systematically organised and analysed to show that the linkages might exists.

It is to be noted that, Haqqul-ibad, that is fulfilling the rights towards others in the realm of financial worship is highly discussed (Benthall, 1999). Additionally, Islamic financial worship (i.e. paying to the rightful recipients their dues in time and the correct amount) may bring barakah, blessings or that is, such worship will improve productivity and will also help the economic expansion, has been discussed by few authors, like Ali (et al. 2014). But a research is due, to analyse the linkages to establish the Quranic doctrine on how overall prayer (i.e. Haqqullah and Haqqulibad, that is, physical and financial prayer, PFP, combined) can increase productivity, as we have also seen numerous western authors trying to ascertain that value-added system may bring fruition to systems and the economy (Adams 2008, Burke et al. 1990, Azzi et al. 1975). But it is understood by Muslims that even if such linkages cannot be empirically tested or justified, still one has to have the fullest faith in the revealed and divine scriptures, "Say: The evil and the good are not alike even though the plenty of the evil attract thee. So be mindful of your duty to Allah, O men of understanding that ye may succeed' (Noble Quran 5.100). Barro et al. (2002) gave the same argument that religious beliefs are at times non-verifiable and therefore may require a degree of abstraction.

Allah ordained human nature to be supreme, in terms of morality, spiritualty and wisdom in the entire epitome of mankind and to surpass in every way from any other creation. Lord Almighty proclaims, "We have certainly created man in the best of stature" (Al Quran 95.4). One can ponder on angels' prostration to Adam 
due to Allah's commandment (Ayat 2.34, 7.11, 18.50). Correspondingly it requires to mention in clear terms that all creations do pray (Quranic Ayat 2:29, 22:18), but diligent prayer (Al Quran 4.162) is expected from human beings, who are the best of creations, and who might want God's pleasure.

"I have chosen thee: listen, then, to the inspiration (sent to thee). Verily, I am Allah: There is no god but I: So serve thou Me (only), and establish regular prayer for celebrating My praise" Quran 20:13-14.

Prophet (PBUH) said, "O Allah, I seek refuge in You for Your pleasure and against Your wrath and in Your forgiveness and against Your punishment and in You from You. I cannot praise You as You can praise Yourself," (Reported by Muslim, Abu Dawud, At-Tirmidhi and Ibn Majah). Allah said in the Holy Book, "And I did not create the jinn and mankind except to worship Me," (51.56). The Holy Scriptures mention, if one wants pleasure and abundance, one should kneel down to prayer and thank to His eternal mercy. Lord Almighty said, "O mankind, you are those in need of Allah, while Allah is the Free of need, the Praiseworthy" (Al Quran 35:15). Further The Lord commands us, "Say (O Muhammad SAW): Verily, I am commanded to worship Allah (Alone) by obeying Him and doing religious deeds sincerely for Allah's sake only and not to show off, and not to set up rivals with Him in worship" (Noble Quran 39.11).

A true salutation and thanksgiving to Lord Almighty will never go unnoticed in front of Lord Almighty (Ayat 65.2). He promised, if one prays with sincerity, one will be ascertained with wisdom and happiness here as well as hereafter (Ayat 28:83). The Prophet (PBUH) said, "No one shall enter Paradise except a believer". Though a question may arise, as seen around, that sometimes a pretentious and ostentatious creature may show his service to Lord, and also his wealth increasing day by day, but one should not make any mistake, that there are two kinds of wealth that prevails, one from His bounty, and one without His pleasure. So one should decide on what should one want? His bounty, guidance and mercy, or His displeasure? So it is high time that one should decide, what should be his course of action. One needs to ponder upon Ayat 39.11-12 and think what Allah has clearly ordained us as mankind.

A true prayer can increase our sustenance (Ayat 6.92, 11.6, 15.19), and increase in our true heavenly pleasure and will give us eternal satisfaction. The way to achieve is simple. Regularity in prayer may give true discipline and a proper meaning in life. It may lead to a routine life, and may assist in honest living, may increase sincerity and trustworthiness in one's daily lives.

To state it humbly from Quranic understanding, one may find that happiness and pleasure in life may be influenced by true prayer. Therefore, prayer can 
affect happiness, pleasure and satisfaction in life. Additionally, Quranic teaching enlightens us, that, if one increases one's daily prayers, one might see a positive increase in heavenly pleasure and satisfaction and which may lead him to be ethical and disciplined (Jewe 2008) and that may increase his productivity and output (Sims 1994).

So from the above it can be deduced that augmentation in daily prayer may lead to increment in heavenly pleasure and worldly satisfaction, which may assist the seeker in achieving increased ethical and disciplined behaviour and that, may assist in intensification in his productivity and output.

Consequently in contemporary literature, it seems that they may have identified a linkage, and that is, prayer may increase satisfaction, which may assist the person to be ethical and disciplined, and hence it may assist that person's productivity and finally his output may increase at a desired rate or ratio.

\section{Literature Review}

Koh et al. (2001) found a strong positive linkage between ethics and satisfaction. Further the said authors found in their study that this may have a positive result in having a career success. This relationship illustrates that there may be a strong relationship between productivity, success and satisfaction, and that can be associated with improved ethical behaviour and best practices.

Corry Azzi and Ronald Ehrenberg (1975) were the first to initiate the prayer issue in political economy after a gap of nearly two hundred years (Mangeloja, 2003). In 1904 Weber explained the role of religion in the developing economies as below, "economic development leads to the secularization, not only of individuals, but also of political and social institutions, including churches themselves. Church services would be predicted to become less demanding, for example, by abandoning the use of special religious language, requiring smaller outlays of time by participants, reducing elaborate rituals and requiring less stringent practices (as quoted by Mangeloja 2003).

Azzi et al. (1975), viewed individual and group religious behaviour as a rational choice. They stated that, "The main aim in religious participation is after-life consumption". They assumed three motives that forces religious activities. The salvation motive for the after-life utility, the consumption motive for current satisfaction, and thirdly social-pressure motive is to excel in trade and career. Iannaccone (1998) found in his research that as pay rises, the religious desire becomes more money-intensive, that is, contributions towards religious activities increases compared to religious attendance. Furthermore, the said author explained the role of religious institution 
that can be seen from two set-ups; One as an authority, and second as a social meeting place.

But Adam Smith clearly stated that, it is the religious environments and setups in society that regulates monopoly practices, and restricts excessive profiteering motives in society. According to Adam Smith, freedom in the religious arena may spawn higher quality religious services (Mangeloja, 2003). And Turnispeed (2002) found a positive linkage between ethics and productivity. On this note Burke et al. (1990) found a saviour linkage between productivity and ethical behaviour. He noted, "The use of the management approaches of efficiency, effectiveness, and economy (the old E's) have not significantly improved productivity measurements. The authors suggest that the application of ethical approaches (plus strategies of evaluation and empathy--the three new E's) might encourage increases in organizational productivity". Furthermore, prayer can improve health conditions, and which are important so as to be productive and also to think in the right way (O'Connor, 2005). "Ethics thus reduce the amount of employee turnover and accompanying lapses in productivity" (Vaux nd.).

Josephson institute promotes that, "At very low cost, business ethics boosts output, promotes recruitment and retention, and reduces misconduct, employee fraud, and absenteeism". So according to this institute, ethics is an essential parameter to productivity. Kolthoff 2006 analysed the case of new public management in terms of ethical practices. McCarty (2007) stated that studies found positive relationship in prayer and healing capacities. Stainer et al. (1995) noted, "It is the combination of productivity, quality and ethics which will establish the management culture of the future".

On explaining the prayer and health relationship, Brown (2009) enlightens, "Prayer, both public and private, is prescribed by most religious traditions. Patterns of prayer are shown to conform to an economic theory of spiritual health. With regard to the frequency of prayer, wages are predicted to correlate negatively, education is predicted to correlate positively, environmental factors that are supportive of prayer are predicted to correlative positively, and the expected "price" for participation in religious activity (the tithe in Judaism and Christianity and the Zakat in Islam) is predicted to correlate negatively. Empirical tests find the predictions of the model are supported for females, but only partially supported for males." (Brown, 2009).

And reporting on the research on fasting, Campante et al. expounds, "... report(ing) two key, quantitatively meaningful results: 1) longer Ramadan fasting has a negative effect on output growth in Muslim countries, and 2) it increases subjective wellbeing among Muslims". (Campante et al. 2013). 


\section{Methods}

The above background leads us to develop a study that will be spread out through particularly purposes and methodology. The purpose of this study was to investigate the linkage between Islamic prayer, spirituality, and productivity. This is among the reasons why this research is needed. By using qualitative description method through content/documents analysis this research basically attempt to complete grounded theory to the relevance references pertaining to Islamic prayer and productivity.

\section{Result and Discussion}

\section{Manifestations in the Islamic Paradigm on the Above Linkages}

There is an urgent need to understand and appreciate the contemporary literature so as to think on how such linkages discussed above in that literature can also be shown in the Islamic doctrine that takes shape. Lord said, "Indeed, I created Jinn and human beings for no other purpose but to worship Me" (Qur'an 51:56). So from Lord's commandments one can clearly see that prayer has a central place, which Muslims do acknowledge, but it requires more scientific exploration to understand and appreciate its further meaning. A research is due to see linkages in prayer and ethical behaviour which may lead to productivity and increase in output in an Islamic paradigm. It might be possible to conduct a survey and look into the aspects of intentions, desires, motivation, through the usage of theory of planned behaviour (TPB), as proposed by Icek Ajzen in 1985 through his article "From intentions to actions: A theory of planned behaviour". In line with TPB, one may able to deduce that, prayer may increase satisfaction which might lead to increase in overall output and henceforth lead to ease the economic burden of society. Here one can also state the kinds of prayer, namely, Physical prayer like salat, hajj, fasting, and Financial prayer like sadaqat, fitrat and zakat. So it needs to be seen, that if Muslims improve both prayers, then it may lead to increase in heavenly pleasure and worldly satisfaction and that may similarly assist the person who prays to have an increase in productivity and output (here and hereafter). Quran further encourages putting extra effort to win Allah's mercy. Besides to be productive, one may have to bear patience and perseverance so as to be successful, productive, and energetic and hence produce the needed outcome with ease. "O you who have believed, seek help through patience and prayer. Indeed, Allah is with the patient" (Quran 2.153).

The question arises; can only one kind of prayer improve the overall situation? The need to have cautions that one kind of prayer may be interlinked with the other kind of prayer. Lot of verses on zakat came just intertwined with prayer, like, 
"And establish prayer and give zakah and bow with those who bow (in worship and obedience)".

Therefore, it is seen that the two kinds of prayers complement each other. The prayer in general is understood in totality, not in partiality. So Physical and Financial Prayer (PFP) may give pleasure, happiness and it may help in increasing output (fiddunia wal Akhirah), as prayer increases the positive energy, which boost the level of productivity and gives a better and sound outcome. One may achieve increase in output without performing such prayers, but it may not be a God sanctioned pleasure endorsed output, that Lord Almighty might have wanted. That might show the differences.

"The first matter that the slave will be brought to account for on the Day of Judgment is the prayer. If it is sound, then the rest of his deeds will be sound. And if it is bad, then the rest of his deeds will be bad," (Recorded by al-Tabarani. According to al-Albani, Sahih al-Jami).

The Prophet (PBUH) said that "Salaat is the pillar of deen and the foundation of Islam. He who upholds salah has upheld Islam and he who leaves salah has left behind religion" (Al-baihaqi).

Rasulullah (SAW) said "What lies between a man and disbelief is the abandonment of prayer" (Agreed upon by Muslim, Abu Dawood and Nasaa'ee as Sahih authentic).

In contemporary studies it is found that, prayer is at times positively related to increase in output, satisfaction, coping with loneliness and feeling of reward here as well as hereafter. But it is said in Islam that the believers will be saved from all sorts of discomforts in the Day of Resurrection until they are granted entrance into Paradise: "(To the righteous soul will be said:) ' $O$ soul in (complete) rest and satisfaction! Come back to your Lord, well pleased (yourself), and well-pleasing unto Him! Enter, then, among My servants. Yea, enter My Heaven" (Al Quran 89:27-30); "And those who feared their Lord will be led to the Garden in crowds: until behold, they arrive there; its gates will be opened; and its keepers will say, 'Peace be upon you! You have done well! Enter here, to dwell therein.' They will say, 'Praise be to Allah, Who has truly fulfilled His promise to us, and has given us (this) land in heritage: we can dwell in the Garden as we will: how excellent a reward for those who work (righteousness)'” (Al Quran 39:73-74).

The question still remains on what sort of prayer that will please Lord Almighty, and that may please Him to increase His bounty and that will reward us here and hereafter.

"Say: My Lord hath commanded justice; and that ye set your whole selves (to Him) at every time and place of prayer, and call upon Him, making your devotion 
sincere" (Al Quran 7:29). "And know that ALLAH cometh in between a man and his heart" (Al Quran 8:24). "O ye who believe turn to ALLAH with sincere repentance: in the hope that your Lord will remove from you your evil deeds and admit you to Gardens beneath which Rivers flow" (Al Quran 66:8). "And whoever repents and does good has truly turned to ALLAH in repentance" (Al Quran 25:71). "Turn ye in repentance to Him, and fear Him: establish regular prayers" (Al Quran 30:31). "Verily the most honoured of you in the sight of ALLAH is (he who is) the most righteous of you" (Al Quran 49:13). "So serve ALLAH, offering Him sincere devotion" (Al Quran 39:2). These verses conform the notion that has already been earlier mentioned, therefore, it can be predicted that an increase in true prayer, may lead to worldly as well as heavenly satisfaction, and that may induce motivation, and that may further tempt to have the right intentions, which may lead to devotion towards productivity and that may lead to improvement in overall output, but the investigation needs to be with empirical soundness to establish scientific linkages in an Islamic framework, as conventional wisdom already conforms such wisdom. So prayer may lead to productivity and output increment, in other words, the link is positively related, and one can learn that from conventional wisdom as well as Quranic understanding.

Since Lord Almighty has already promised that, regular prayers will ensure success, piety, and abundance, Muslims are encouraged to follow suit. But the prayer must be true prayers with best of all intentions, not with mischievous content or intent. Prayer will give the seeker mercy, positive thinking, enlightenment, perseverance, patience, obedience, understanding, comprehension and wisdom and finally will guide one through. Likewise, Lord Almighty clarifies, "Allah burdens not a person beyond his scope. He gets reward for that (good) which he has earned, and he is punished for that (evil) which he has earned. "Our Lord! Punish us not if we forget or fall into error, our Lord! Lay not on us a burden like that which You did lay on those before us (Jews and Christians); our Lord! Put not on us a burden greater than we have strength to bear. Pardon us and grant us Forgiveness. Have mercy on us. You are our Maula (Patron, Suppor-ter and Protector, etc.) and give us victory over the disbelieving people" (Al Quran 2.286). Thus one need true and sincere prayers, true guidance and immense mercy during one's activities and while enlightening him with His everlasting wisdom and blessings. Here a word of caution is required; there might be a difference between knowledge and guidance. As Al Quran testifies, many people may have knowledge, but very few are guided by it. Knowledge is easy to obtain, guidance is only from Allah. Whomsoever Allah guides, no one can misguide, whomsoever Allah leaves to go astray, no one can bring him back to the path of guidance. "Verily, you (O Muhammad) guide not whom you like" [al-Qasas 28:56] and "And verily, you (O Muhammad) are indeed guiding (mankind) to the Straight Path" [al-Shooraa 42:52]. 
On explaining Siraat or straight path while explaining Surah Fatihah (LinguisticMiracles.com), the authors stated that Siraat is a kind of path, from A to $B$, without any alternate route. So, for instance if one deviates slightly from that path, the Siraat GPS may not calculate a new route, rather it would instruct him to rejoin the point of the siraat that he deviated from, and there may be no shortcuts. That's the reason in Arabic language, Siraat may not even have plurals, therefore, the surah Fatihah begins with Allah's sovereignty over people and the ending is how people should be divided — not by ethnicities, or languages, but rather on their actions, knowledge and results. Therefore, the life of the Muslim should be in balance. According to a certain narration, Umar bin Khattab described taqwa as having a sense of balance.

So one can see a theoretical relationship between the above variables, but if a study can be conducted to verify, will be an immense success. Even if the results are not satisfactory, as contemporary scientists have said, then there is no issue of concern. Our faith that leads us as Muslims and makes us who we truly are.

"If We had sent down this Qur'an upon a mountain, you would have seen it humbled and coming apart from fear of Allah. And these examples We present to the people that perhaps they will give thought" (Surah Al Hashr verse 21).

\section{The Science and Secrets of Islamic Prayer}

Sujud or Sajdah is a distinctive locus in a Muslim's at least five time call towards His Lord. Though it is not an exercise per se, but still Holy Prophet Muhammad (PBUH) has clearly mentioned in pure terms that prayer is a cure for many illnesses (reported by Ibn Majah). Regular prayers may protect Muslims from many ailments which they may not even know. Prayer supposed to increase a person's iman, which may also motivate the person to do good as it may increase his hope, and it may in turn assist him to be more productive and a happy person. And this prayer activity also encourages the believer to recite the verses of the Holy Quran, which has immense power in the believer's daily lives.

Abu Huraira (radiAllahu anhu) reported that the messenger of Allah (sallAllaahu 'alayhi wa sallam) said: "The nearest a servant comes to his Lord is when he is prostrating himself, so make supplication (in this state)" [Sahih al-Bukhari]. A'ishah Siddiqa (radiAllahu anha) narrated that the Prophet (sallAllaahu 'alayhi wa sallam) used to prolong the prostration to such an extent that one could recite fifty verses (of the Qur'an) before he would lift his head [Sahih al-Bukhari].

"Sajdah is a unique position as this is the only position in which brain (or head) becomes lower than the heart and hence for the first time the blood gushes towards 
the brain with full force whereas in all other positions (even when lying) brain is above the heart when it has to work against gravity to send blood to the brain".

It has been highly discussed among intellectual Muslims that in that sujud position, the increased blood supply to the brain may give true nourishment and it may also help towards improved memory, vision, hearing, concentration, psyche and all other cognitive abilities. It is said that who offers regular prayer may have more will power and may be able to cope with the difficulties of life in a much improved manner. It is further stated that it may lead to less incidence of headaches, psychological problems and other defects of cognitive function.

"In the unique position of Sajdah the neck muscles get best exercise. They have to bear the load when the forehead lies at the ground hence the neck muscles become stronger. One can note the tense pressure at the neck muscles in the position of Sajdah specially the active motion of the neck and the facial muscles when the head is being lifted... and it will be noticed that they are in a very active motion... More strong cervical muscles mean the cervical vertebra will be better protected. Strength of cervical muscles is important as the head rests upon cervical vertebra supported by cervical musculature".

So to state all the benefits of prayers, a full research paper needs to be initiated with concrete steps, and which may not give the scope to discuss in the present topic. The benefits are immense; in fact to all who prays, even it boosts the sexual health, as reported by some research findings

\section{Conclusion}

Thus in the end, it can be seen that Islamic prayers play a noteworthy role in daily lives and developments. But what is required is that, an exhaustive research need to be initiated and methodically examined on the benefits, and to unearth the ultimate aim of the present research particularly to see if there can be seen a sound linkage between individual or group productivity with increased ritual prayers and financial prayers and also if these findings can assist the economy to experience an increase in total output. Further research on this notion seems highly desirable, though it cannot be denied that huge research in terms of psychological and medical aspects have already been researched and still ongoing. But a comprehensive research by social researchers and policy makers, combined with Islamic jurists, is still due, and that is the kind request to the intellectual capacities to come forward and fulfil the desired tasks. Besides, it would be even an improved scenario if such findings can be empirically tested in an Islamic framework, as Muslims belief in Quran and Sunnah gives enormous understanding about such linkages, and that has already been ascertained by many contemporary findings. 


\section{References}

Achour, M. et.al. (2014). Measuring religiosity and its effects on personal wellbeing: a case study of Muslim female academicians in Malaysia. Journal of religion and health. Vol. 54 (3): 984-997.

Adams, T. (2008). Impact of prayer on the relationship between supervisory support and employee's perception of workplace equity. Emerging Leadership Journal. Vol. 1: 3-13.

Ai, A.L. et.al. (2003). RESEARCH: The Effect of Religious-Spiritual Coping on Positive Attitudes of Adult Muslim Refugees From Kosovo and Bosnia. The International Journal for the Psychology of Religion. Vol. 13 (1): 29-47.

Ajzen, I. (1985). From intentions to actions: A theory of planned behavior. Berlin: Springer.

Ali, I \& Z.A. Hatta. (2014). Zakat as a Poverty Reduction Mechanism Among the Muslim Community: Case Study of Bangladesh, Malaysia, and Indonesia. Asian Social Work and Policy Review. Vol. 8 (1): 59-70.

Azmi, I.A.G. (2012). The Implementation of Islamic Business Practices of Women Traders: A Study in An Islamic State in a Developing Country. Sciences. Vol. 4 (5): 229-235.

Azzi, C. \& R. Ehrenberg. (1975). Household allocation of time and church attendance. The Journal of Political Economy. Vol. 5: 27-56.

Benson, H. \& M.Z. Klipper. (1999). The relaxation response. New York: Avon.

Benthall, J. (1976). Financial worship: the Quranic injunction to almsgiving. Journal of the Royal Anthropological Institute. Vol. 2: 27-42.

Black, H.K. (1999). Poverty and prayer: Spiritual narratives of elderly AfricanAmerican women. Review of Religious Research. Vol. 3: 359-374.

Blanchard, K. \& N.V. Peale. (2011). The power of ethical management. London: Random House,

Brown, M.J. (2000). Panem Nostrum: The Problem of Petition and the Lord's Prayer. The Journal of Religion. Vol. 4: 595-614.

Brown, T.T. (2009). Rational praying: The economics of prayer. The Journal of SocioEconomics. Vol. 38 (1): 37-44.

Burke, F. \& A. Black. (1990). Improving organizational productivity: Add Ethics. Public Productivity \&amp; Management Review. Vol. 5: 121-133.

Campante, F.R. \& D.H. Yanagizawa-Drott. (2013). Does Religion Affect Economic Growth and Happiness? Evidence from Ramadan. Working Paper. No. w19768. National Bureau of Economic Research. 
Deshpande, S.P. et.al. (2000). Ethical climates and managerial success in Russian organizations. Journal of Business Ethics. Vol. 23 (2): 211-217.

Disley, E. (1991). Degrees of glory: protestant doctrine and the concept of rewards hereafter. The Journal of Theological Studies. Vol. 4: 77-105.

Dossey, L. (1996). Prayer is Good Medicine: How to Reap the Healing Benefits of Prayer. San Francisco: Harper.

Doufesh, H. et.al. (2013). Assessment of heart rates and blood pressure in different salat positions. Journal of Physical Therapy Science. Vol. 25 (2): 211-214.

Dusek, J.A. et.al. (2002). Study of the Therapeutic Effects of Intercessory Prayer (STEP): study design and research methods. American Heart Journal. Vol. 143 (4): 577-584.

Emmons, R.A. \& M.E. McCullough. (2003). Counting Blessings Versus Burdens: an Experimental Investigation of Gratitude and Subjective Well-being in Daily Life. Journal of personality and social psychology. Vol. 84 (2): 377-390.

Fincham, F.D. et.al. (2008). Spiritual Behaviors and Relationship Satisfaction: A Critical Analysis of The Role of Prayer. Journal of Social and Clinical Psychology. Vol. 27 (4): 362-388.

Francis, L.J. \& J. Astley. (2001). Psychological perspectives on prayer. London: Gracewing Publishing,

Fredrickson, B.L. et.al. (2008). Open Hearts Build Lives: Positive Emotions, Induced Through Loving-kindness Meditation, Build Consequential Personal Resources." Journal of personality and social psychology. Vol. 95 (5): 1045-1054.

Garcia-Zamor, J.C. (2003). Workplace Spirituality and Organizational Performance. Public administration review. Vol. 63 (3): 355-363.

Gattiker, U.E. \& L. Larwood. (1998). Predictors for Managers' Career Mobility, Success, and Satisfaction. Human relations. Vol. 41 (8): 569-591.

George, C.V.R. (1993). God's Salesman: Norman Vincent Peale \& the Power of Positive Thinking. Oxford: Oxford University Press.

Henry, H.M. (2015). Spiritual Energy of Islamic Prayers as a Catalyst for Psychotherapy. Journal of Religion and Health. Vol. 54 (2): 387-398.

Hoodbhoy, P. (1991). Islam and science: Religious orthodoxy and the battle for rationality. London: Zed books

Huff, T.E. (1996). Can scientific knowledge be Islamized? Social epistemology. Vol. 10 (3): 305-316. 
Huff, T.E. (2003). The rise of early modern science: Islam, China and the West. Cambridge: Cambridge University Press,

Iannaccone, L.R. (1998). Introduction to the Economics of Religion. Journal of economic literature. Vol. 10: 1465-1495.

Ibrahim, F. \& S. Ahmad. (2012). Assessment of Upper Body Muscle Activity During Salat and Stretching Exercise: A pilot Study. In Biomedical and Health Informatics (BHI), 2012 IEEE-EMBS International Conference on: 412-415.

Isfahani, A.N. \& M. Nobakht. (2013). Impact of Spiritual Intelligence on the Staff Happiness (Case Study: Golpayegan Petrochemical Company). International Journal of Academic Research in Business and Social Sciences. Vol. 3 (7): 253-260.

Islam, S. (2013). An Overview of Islamic Managerial Finance: Comparative Study with the Conventional Version. European Journal of Business and Management. Vol. 5 (11): 182-193.

Johnson, P.E. (1953). A psychological Understanding of Prayer. Pastoral Psychology. Vol. 4 (6): 33-39.

Koh, H.C. \& H.Y. El'Fred. (2001). The link between organizational ethics and job satisfaction: A study of managers in Singapore. Journal of Business Ethics. Vol. 29 (4): 309-324.

Kolthoff, E. et.al. (2006). The Ethics of New Public Management: is Integrity at Stake?." Public Administration Quarterly. Vol. 20: 399-439.

Larimore, W.L. et.al. (2002). Should clinicians incorporate positive spirituality into their practices? What does the evidence say? Annals of Behavioral Medicine. Vol. 24 (1): 69-73.

Locke, E.A. (1970). Job Satisfaction and Job Performance: a Theoretical Analysis. Organizational Behavior and Human Performance. Vol. 5 (5): 484-500.

Mangeloja, E. (2005). Economic Growth and Religious Production Efficiency. Applied Economics. Vol. 37 (20): 2349-2359.

Masters, K.S. \& G.I. Spielmans. (2007). Prayer and Health: Review, Meta-analysis, and Research Agenda." Journal of behavioral medicine 30, no. 4. 329-338.

McCarty, W.B. (2007). Prayer in the Workplace: Risks and Strategies to Manage Them. Business Renaissance Quarterly. Vol. 2 (1): 97-110.

McCleary, R.M. \& R.J. Barro. (2006). Religion and Political Economy in an International Panel. Journal for the Scientific study of religion. Vol. 45 (2): 149-175.

Mitroff, I.I. \& E.A. Denton. (1999). A study of spirituality in the workplace. MIT Sloan Management Review. Vol. 40 (4): 83-90. 
Mohiuddin, Md.G. (2012). Management Views in Islamic literature: a Conceptual Analysis of The Way of New Management Dimensions. International Journal of management. Vol. 3 (2): 411-424.

Nasr, S.H. (2013). Islamic Spirituality: Foundations. London: Routledge.

Nazri, M.K.N.Z. et.al. (2011). The Concept of Rewards and Punishments in Religion: A Special Reference to Kitab Al-Adab of Sahih Bukhari. World. Vol. 1 (4): 249-254.

O'Connor, P.J. et.al. (2005). Characteristics of Adults Who Use Prayer as an Alternative Therapy. American Journal of Health Promotion. Vol. 19 (5): 369-375.

Peale, N.V. (2012). The power of positive thinking for young people. New York: Random House.

Peale, N.V. (2013). You can if you think you can. New Jersey: Simon and Schuster.

Kocka, J. (2010). Work in a modern society: the German historical experience in comparative perspective. Vol. 3. Berghahn Books.

Rassool, G.H. (2000). The Crescent and Islam: Healing, Nursing and The Spiritual Dimension: Some Considerations Towards an Understanding of The Islamic Perspectives on Caring. Journal of advanced nursing. Vol. 32 (6): 1476-1484.

Saqeb, G.N. (2000). The Islamisation of Education since the 1977 Makkah Education Conference: Achievements, Failures and Tasks ahead. Muslim Education Quarterly. Vol. 18 (1): 39-64.

Sardar, Z. (ed). (1984). The Touch of Midas: science, values, and environment in Islam and the West. Manchester: Manchester University Press,

Sarea, A. (2012). Zakat as a Benchmark to Evaluate Economic Growth: An Alternative Approach. International Journal of Business and Social Science. Vol. 3 (18): 1711-1720.

Sen, A. (2009). Capitalism Beyond The Crisis. The New York Review of Books. Vol. 56 (5): 26-34.

Sims, R.R. (1994). Ethics and organizational decision making: A call for renewal. Canada: Greenwood Publishing Group

Smith, A. (2010). The Theory of Moral Sentiments. London: Penguin

Spohn, W.C. (2001). Spiritual Practices: The true test of spirituality. Dialog. Vol. 40 (4): 277-283.

Stainer, A. \& L. Stainer. (1995). Productivity, quality and ethics-a European viewpoint. European Business Review. Vol. 95 (6): 3-11. 
Syed, I.B. (2003). Spiritual Medicine in The History of Islamic Medicine. Journal of the International Society for the history of Islamic medicine. Vol. 2: 45-49.

Tribe, K. (1999). Adam Smith: critical theorist? Journal of economic literature. Vol. 30: 609-632.

Turnipseed, D.L. (2002). Are good soldiers good?: Exploring the Link Between Organization Citizenship Behavior and Personal Ethics. Journal of business research. Vol. 55 (1): 1-15.

Viswesvaran, C. \& S.P. Deshpande. (1996). Ethics, success, and job satisfaction: A test of dissonance theory in India. Journal of Business Ethics. Vol. 15 (10): 1065-1069.

Whittington, B.L. \& S.J. Scher. (2010). Prayer and Subjective Well-being: An Examination of Six Different Types of Prayer. International Journal for the Psychology of Religion. Vol. 20 (1): 59-68.

Williams, D.R. \& M.J. Sternthal. (2007). Spirituality, Religion and Health: Evidence and Research Directions. Medical journal of Australia. Vol. 186 (10): 847-860.

Young, LA. (1997). Rational choice theory and religion: Summary and assessment. London: Psychology Press, 